\title{
Television Journalism During Terror Attacks
}

Mogensen, Kirsten

Publication date:

2007

Document Version

Early version, also known as pre-print

Citation for published version (APA):

Mogensen, K. (2007). Television Journalism During Terror Attacks. Paper presented at Media War Conflict, Launch Conference, Milwaukee, United States. http://www.warandmedia.org/events.htm\#mwc

\section{General rights}

Copyright and moral rights for the publications made accessible in the public portal are retained by the authors and/or other copyright owners and it is a condition of accessing publications that users recognise and abide by the legal requirements associated with these rights.

- Users may download and print one copy of any publication from the public portal for the purpose of private study or research. - You may not further distribute the material or use it for any profit-making activity or commercial gain.

- You may freely distribute the URL identifying the publication in the public portal.

\section{Take down policy}

If you believe that this document breaches copyright please contact rucforsk@kb.dk providing details, and we will remove access to the work immediately and investigate your claim. 


\section{Television Journalism}

During Terror Attacks 


\section{Pubjljc Service}

- How can journaljists help socjety through a terror related acute national crisis that may threaten the basic structure and core values of the social system?

The case of September 11, 2001.

- $A B C$, NBC, CBS, CNN, Fox News. 


\section{Profiessional Norms}

$\checkmark$ Professional ethics discusses moral solutions to professional problems. Janik (1994):

$\checkmark$ Professionals' problems by their very nature are problems specific io professioral practice, i.e., ethical problems that arise in the course of carrying out the tasks for which one has been professionally trained... 


\section{Methods}

u Personal interviews

with 37 journalists

that covered the

events for $\mathrm{ABC}$, CBS, NBC, CNN, FOX News and MSNBC.

- Content analysis of the coverage the first 24 hours.

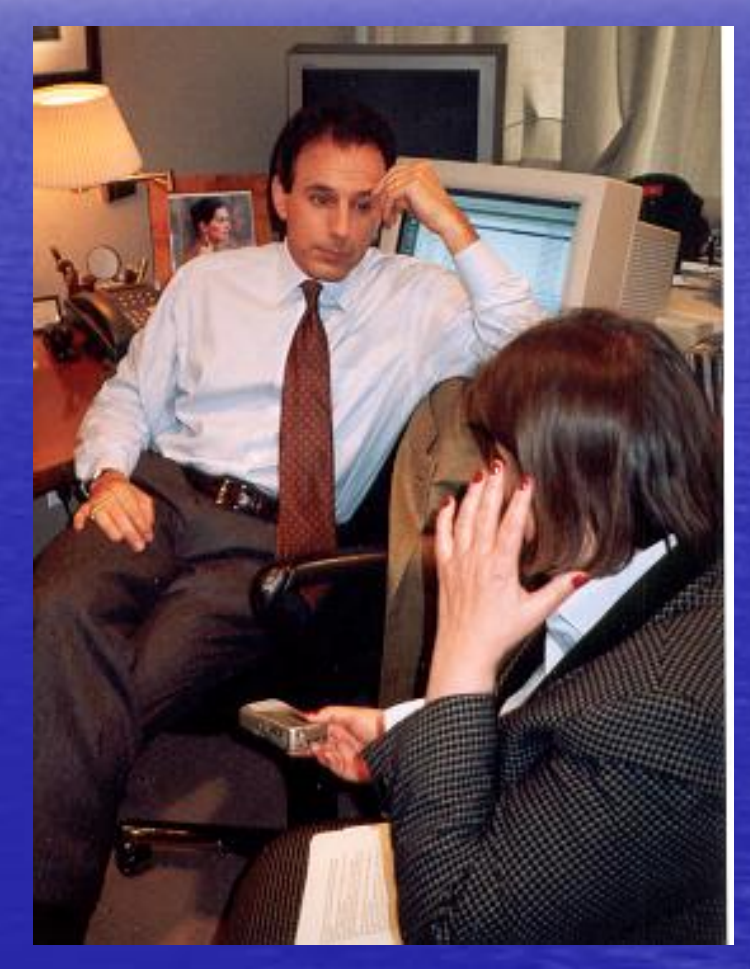




\section{First ajd to audjence members}

$\checkmark$ Ratjonal thjoksing is supported by timely, accurate information; aclmission of and promptly correction-of mistakes; explanation of condifions regarding production of the coverage; involvement of the audjience.

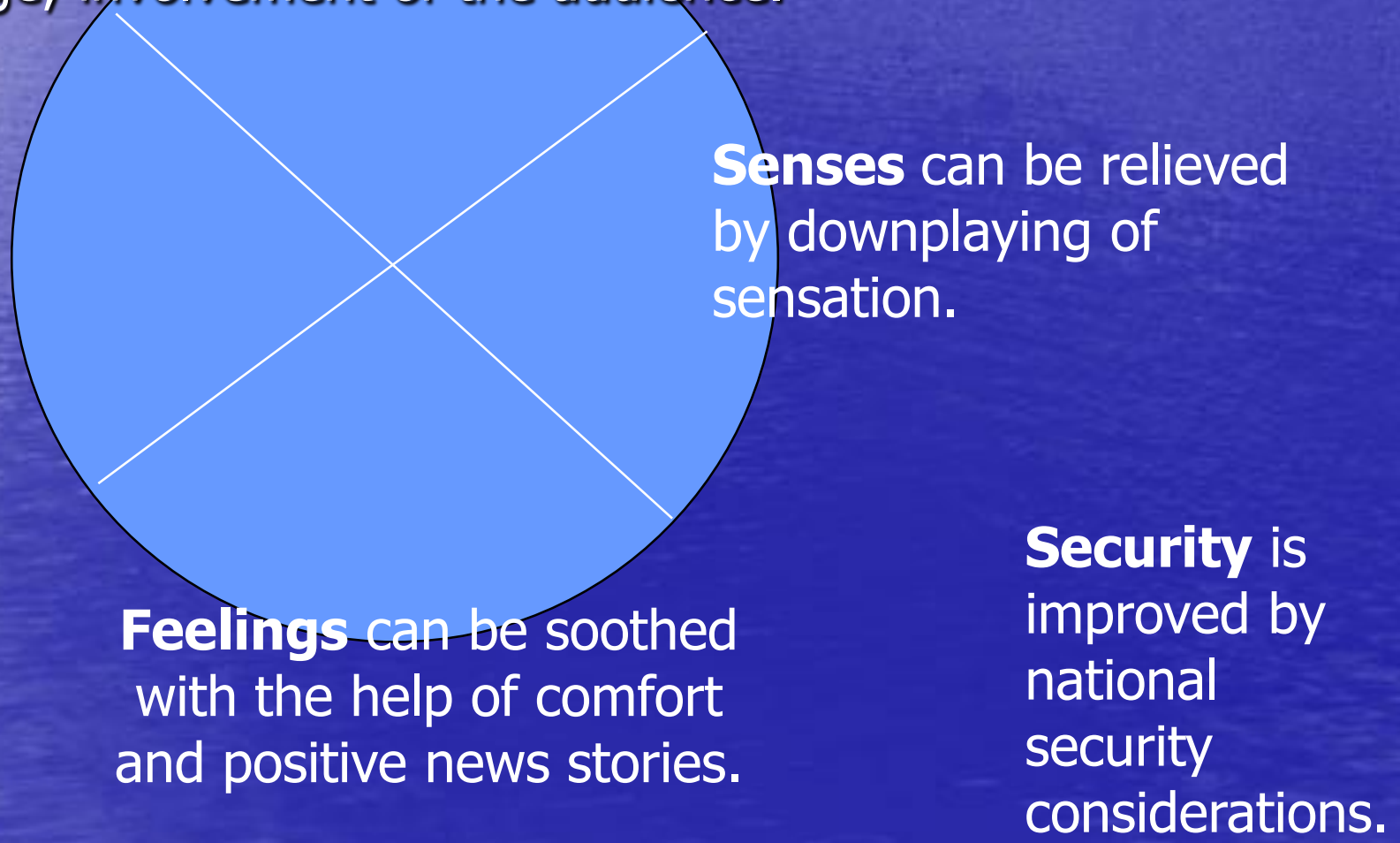

The figure is inspired by C.G. Jung (Jacobi 1987). 


\section{Injormation as soon as possible}
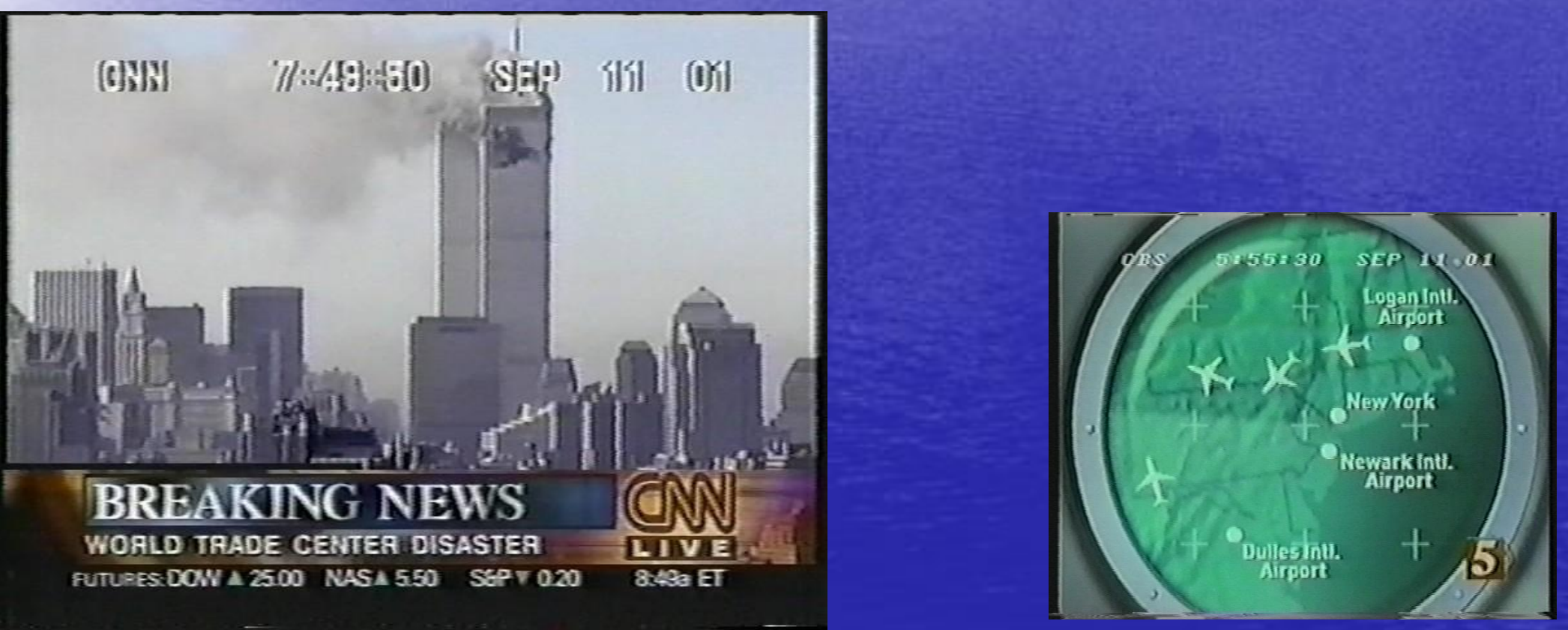


\section{Honesty is the best policy}

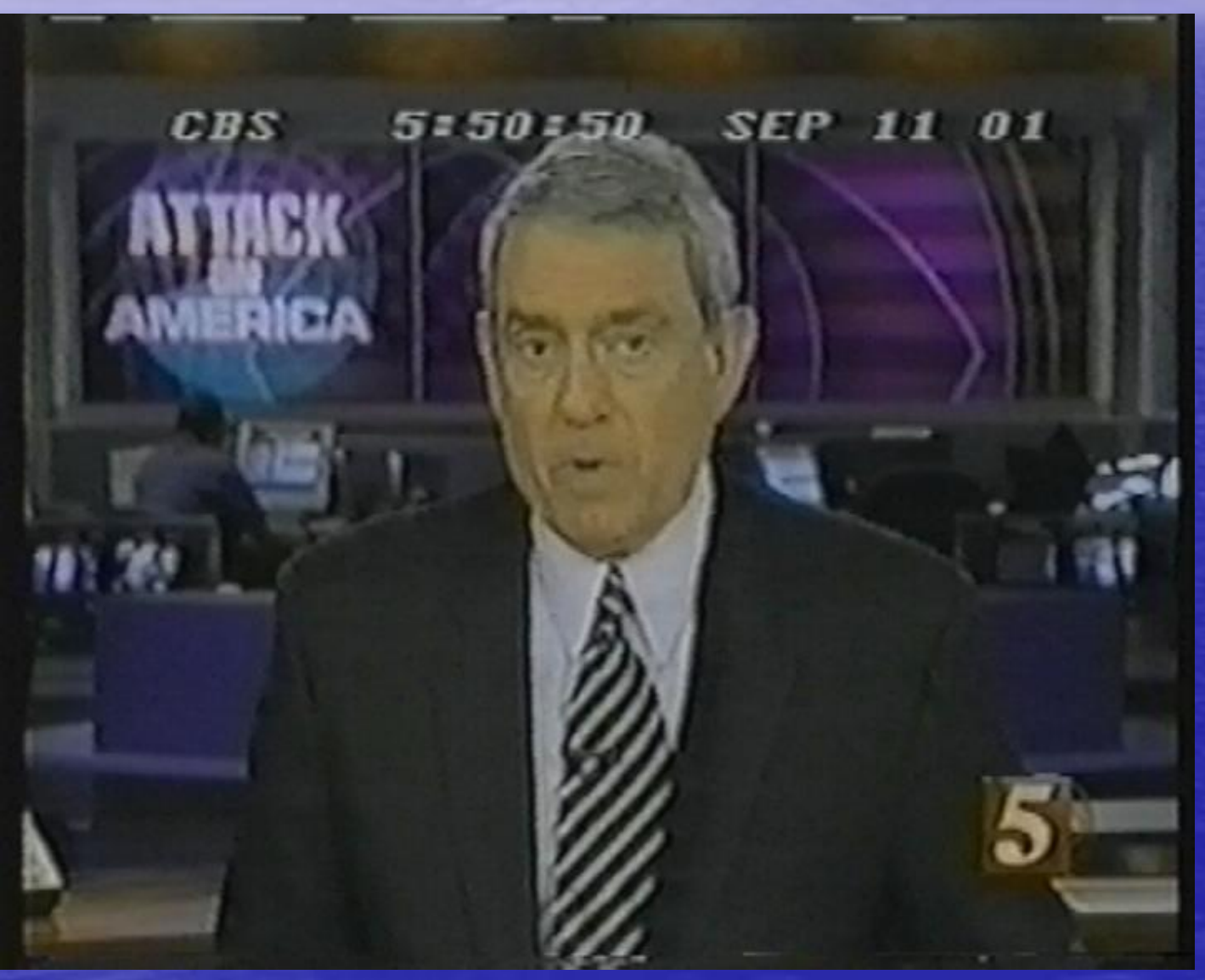




\section{We're all in this together}
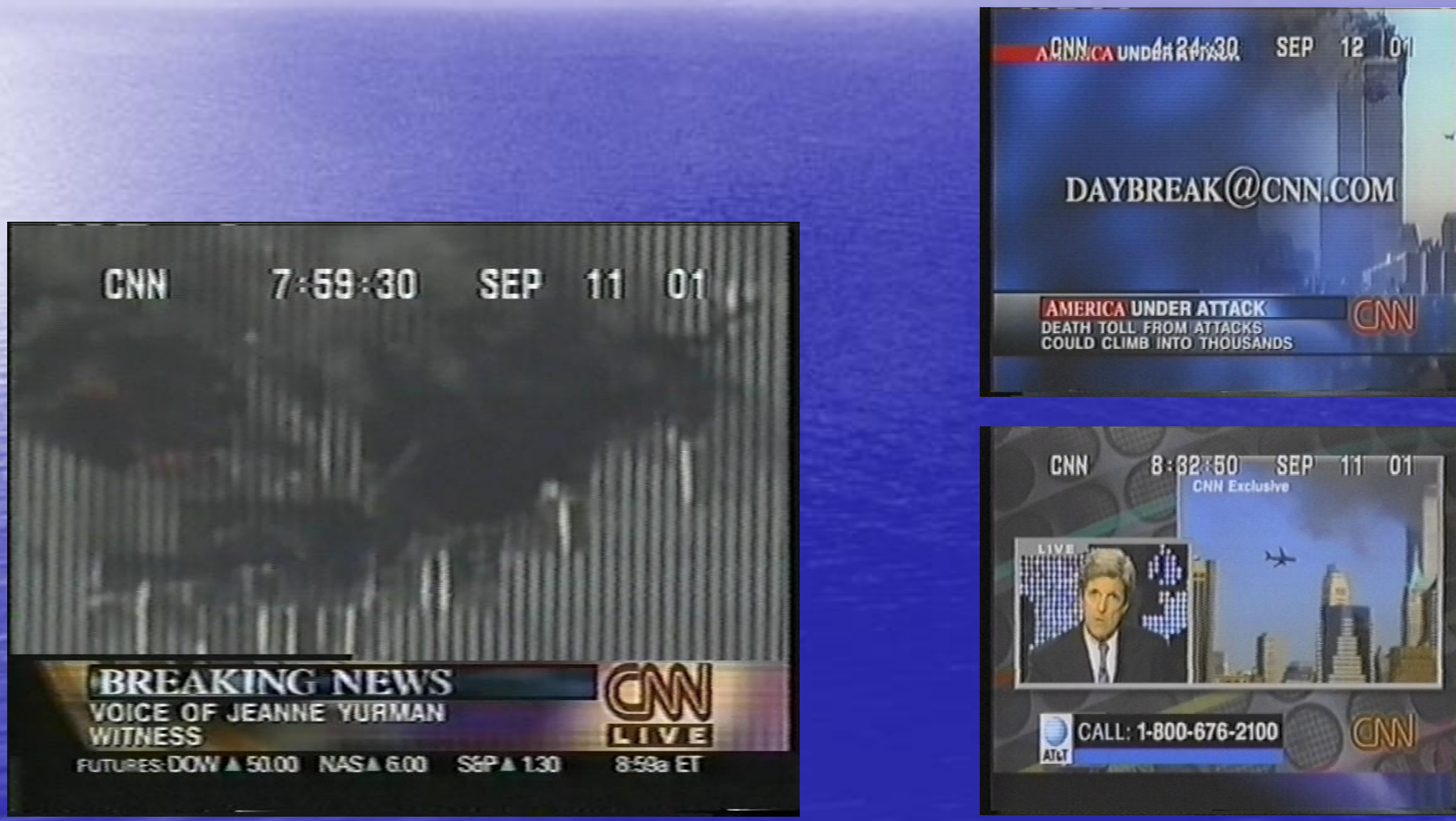


\section{We cannot show emotion}
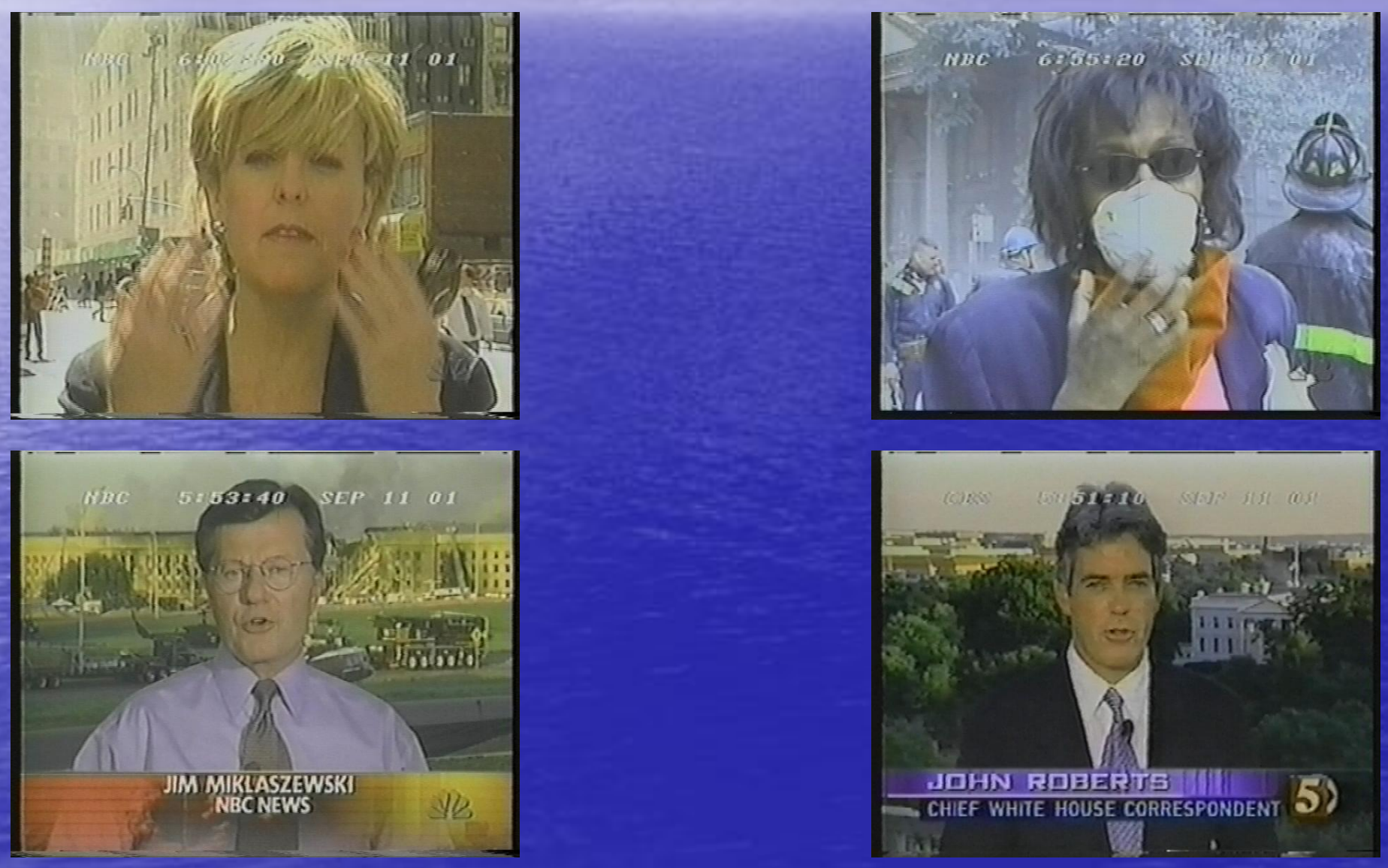


\section{Reassurance is a by-product of journalissm}
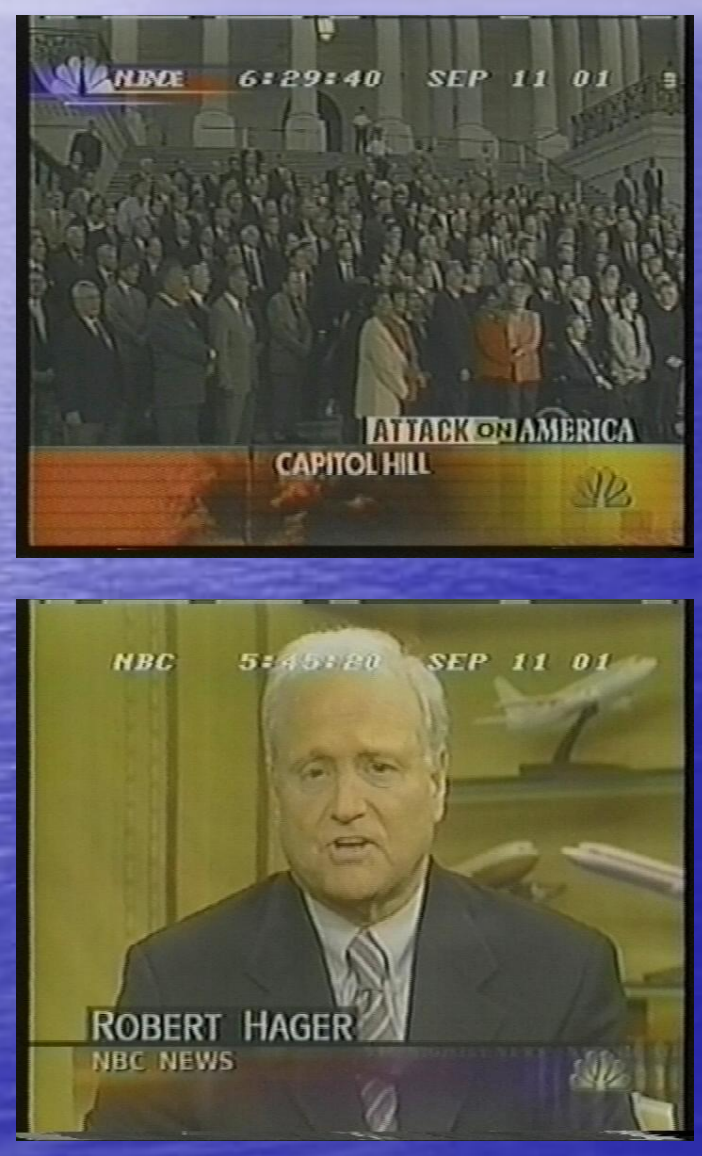
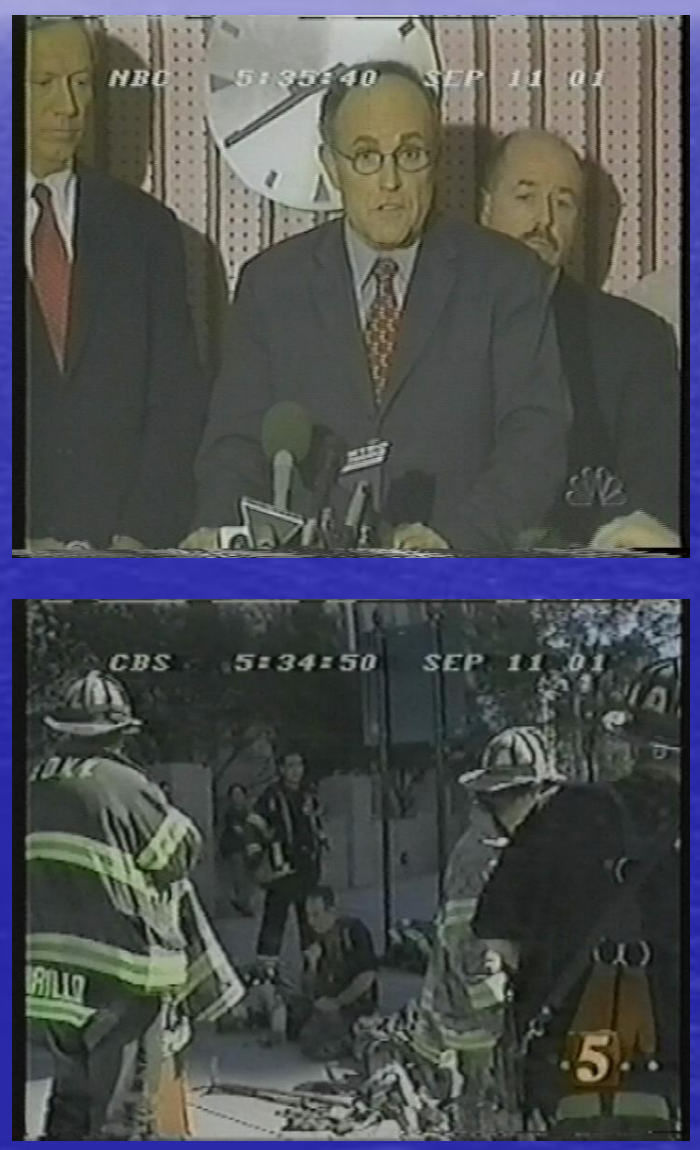


\section{Sensatjonalism the normal; cownplay the sensational}
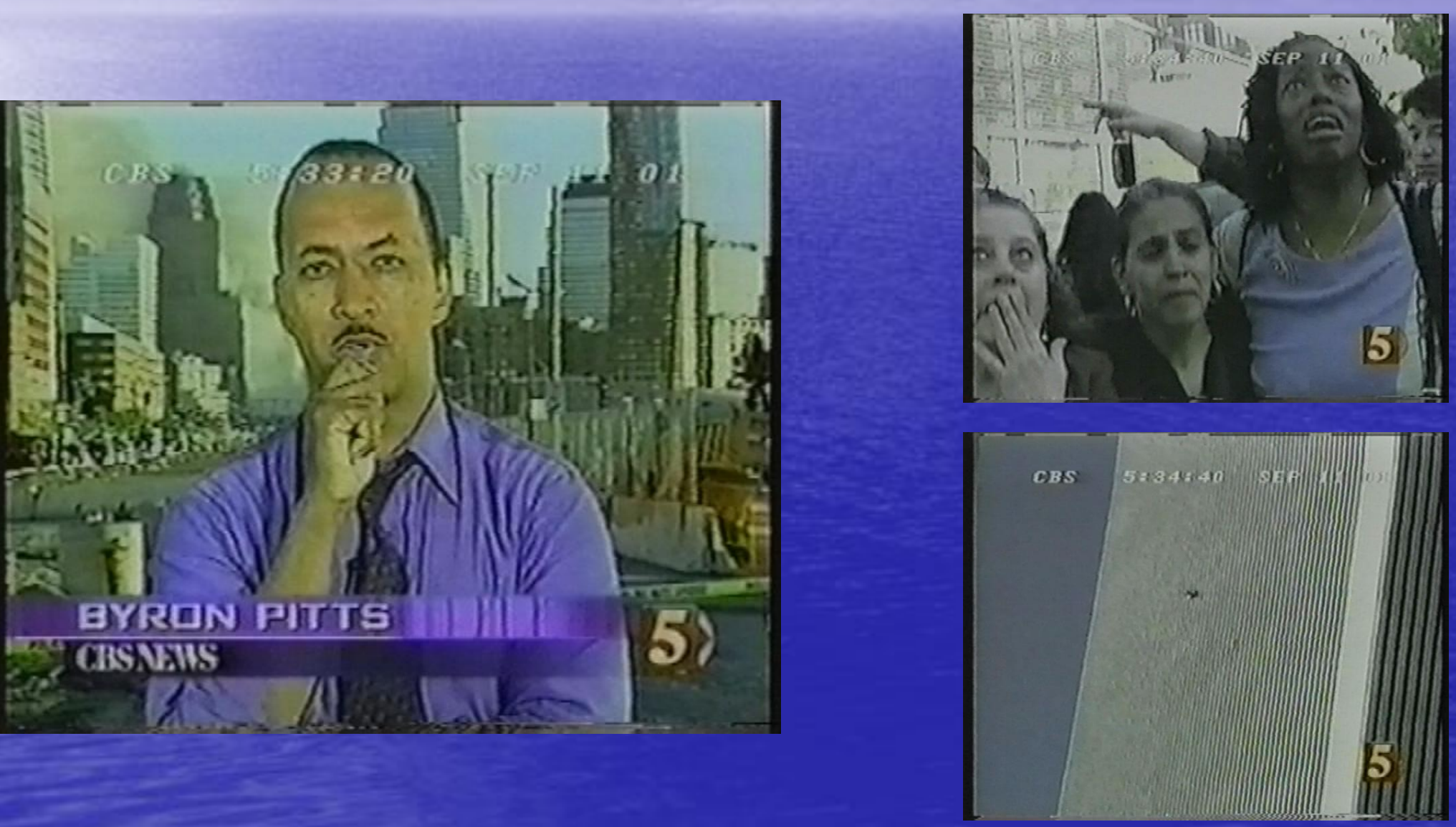


\section{Avoid stereotypes}
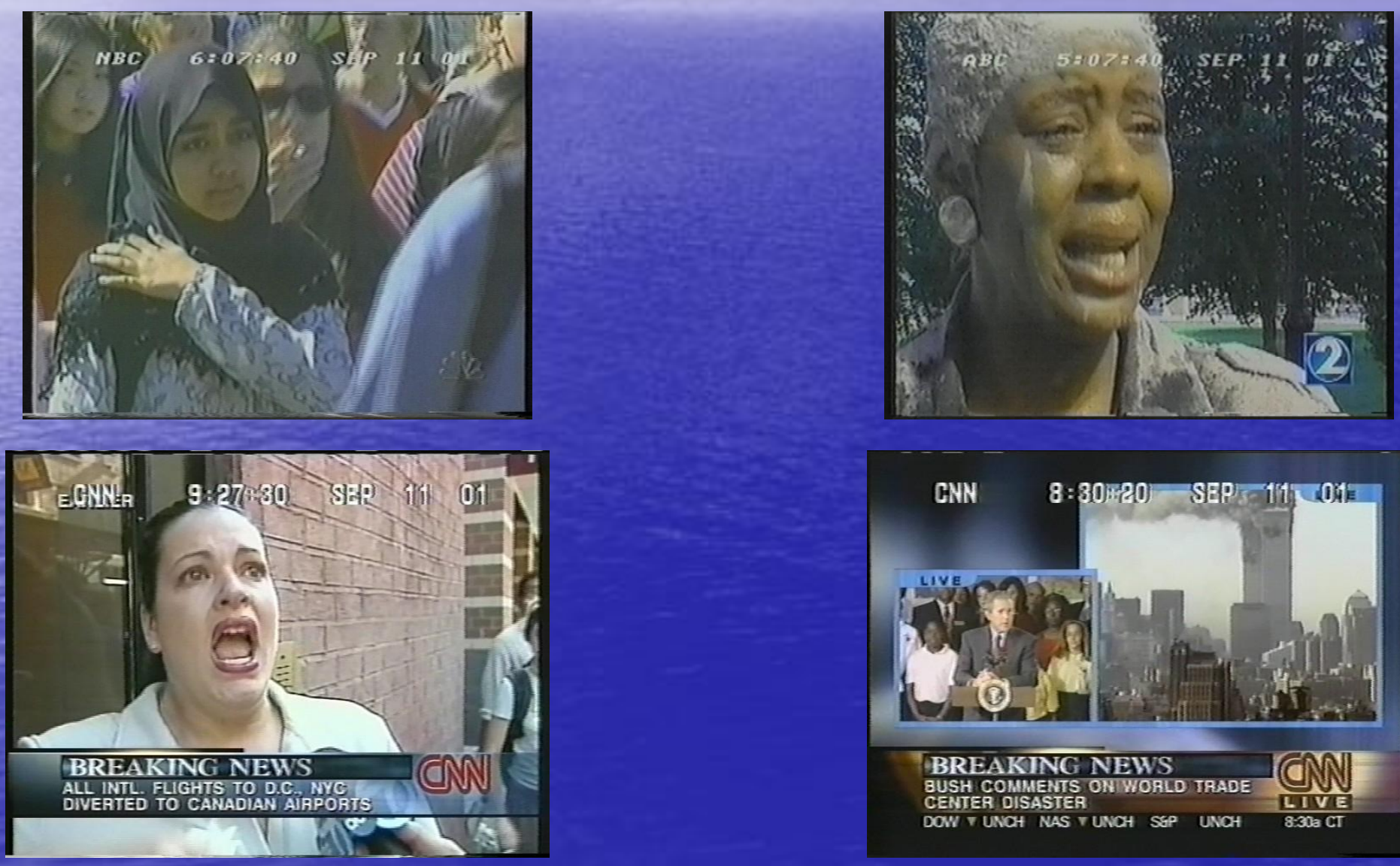


\section{Avojd national sources with extremist views}
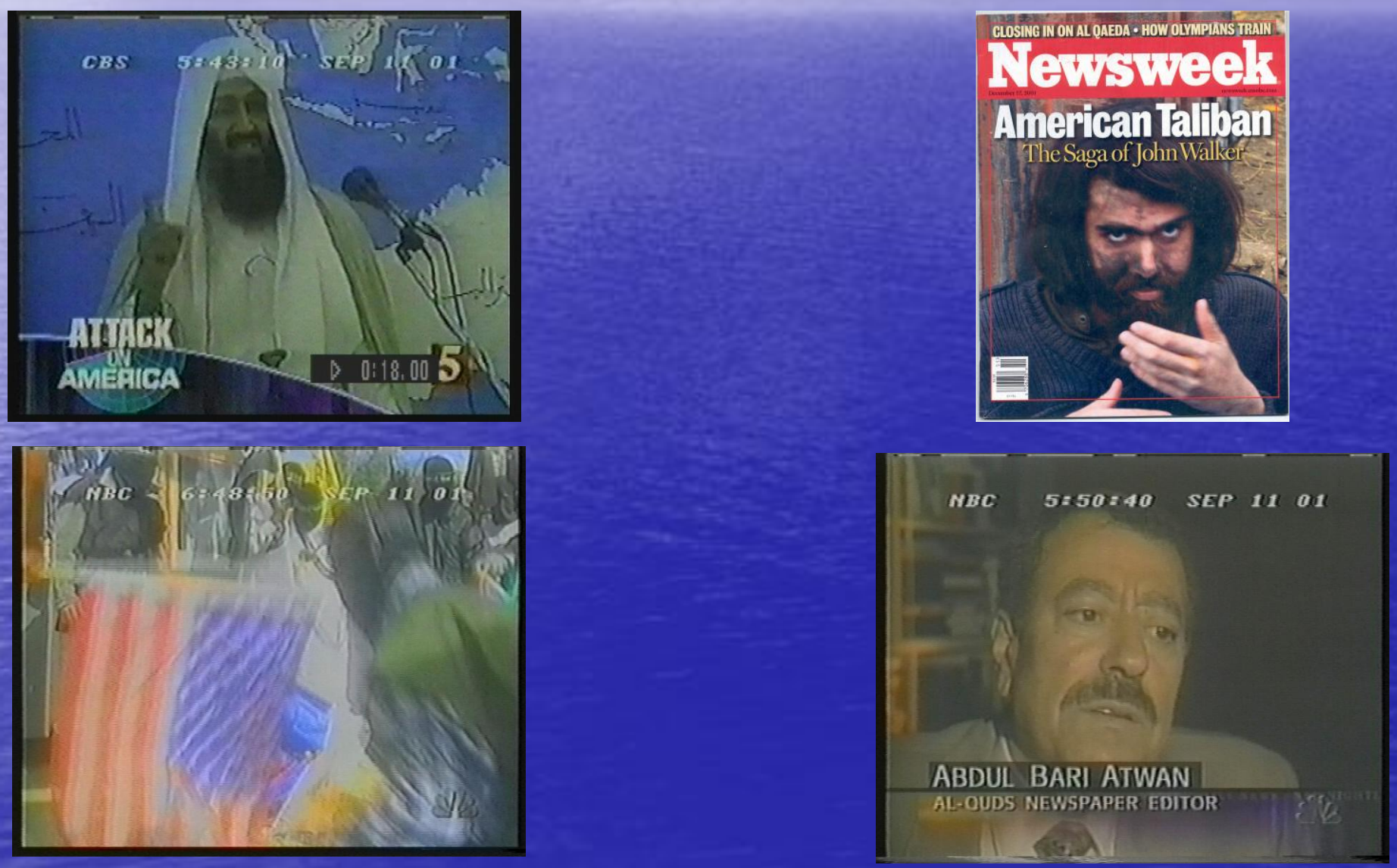


\section{Find the good among the bad}
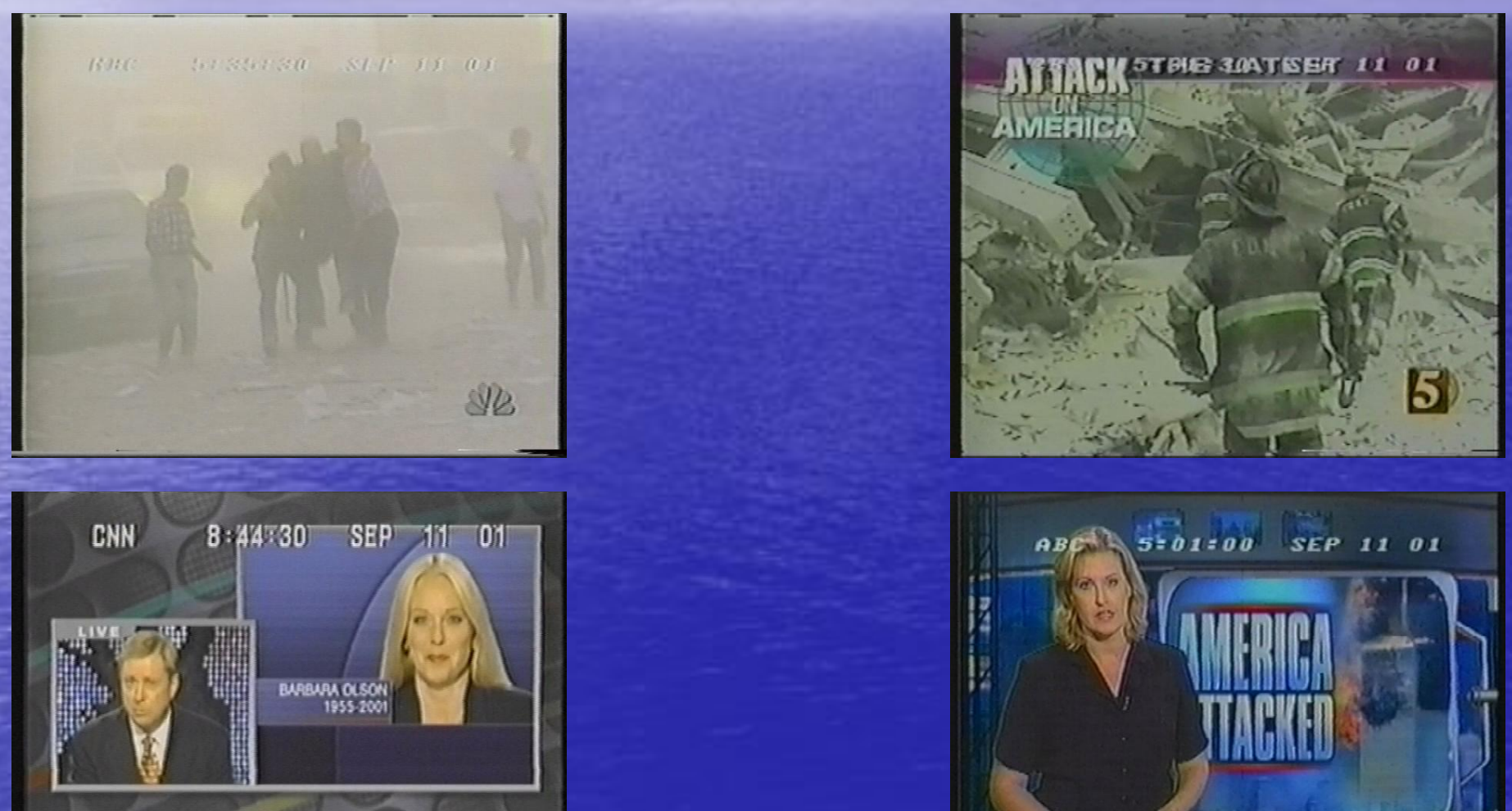

AMERICA UNDER ATIAOK FAA NO US. COMMERCIAL AIR

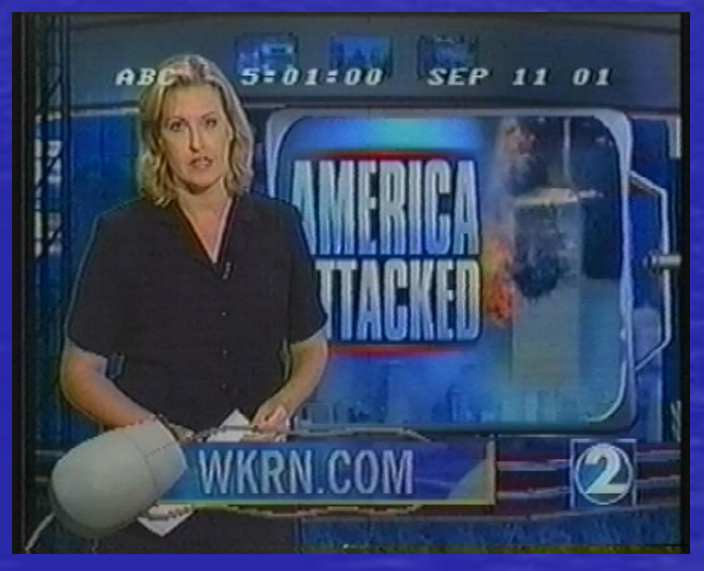




\section{Journaljism is a public service}
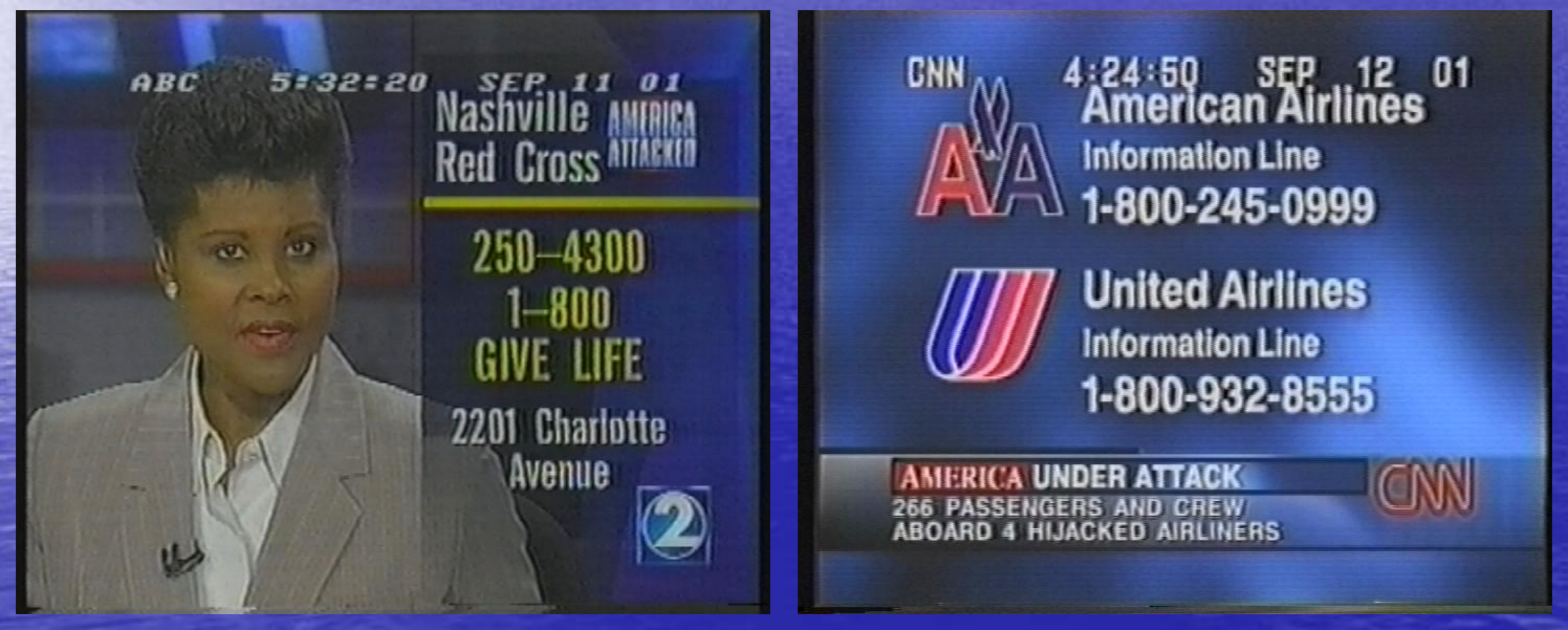


\section{Development of professional norms}

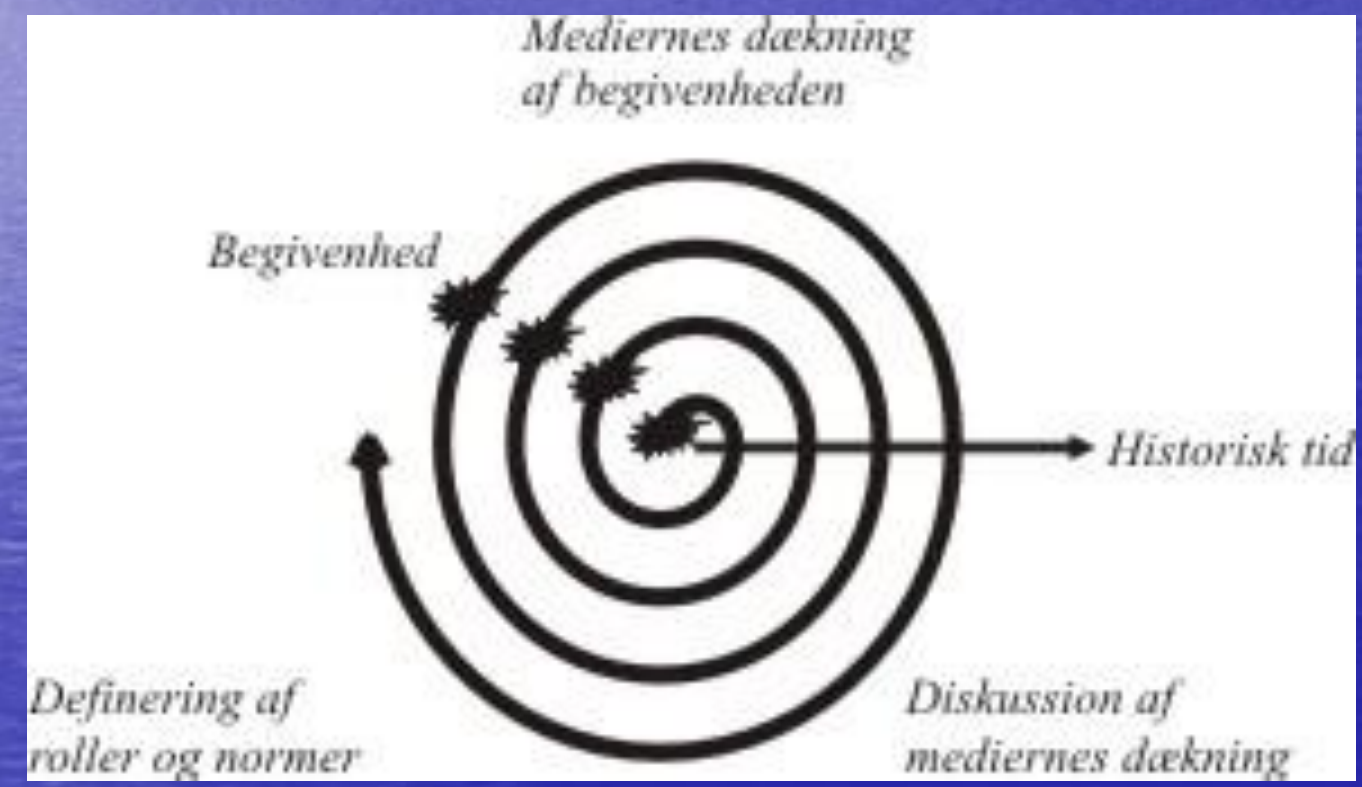




\section{Vjewers' satisfaction?}

(9) out of 10 watched the coverage on television.

$\checkmark$ Most were satisfied with the coverage.

ᄀ Prajise: Accuracy, immediacy, commitment to conitjnuous coverage, professionalism of anchors, video footage.

- Complaints: Repetition of information and pictures, too sensational.

- (WestGroup Research 2001). 


\section{Watchdog for democracy}
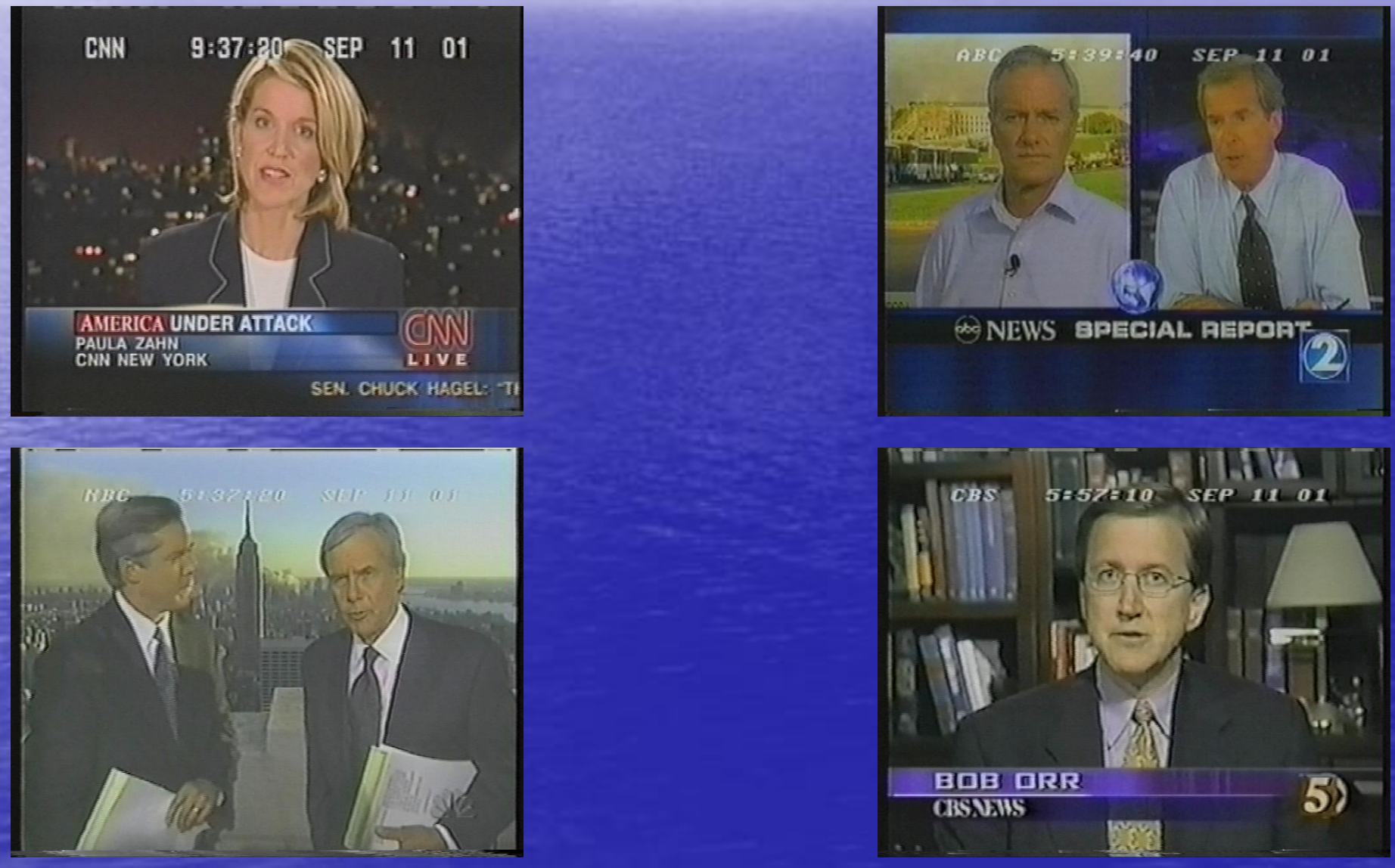


\section{Moral reasoning}
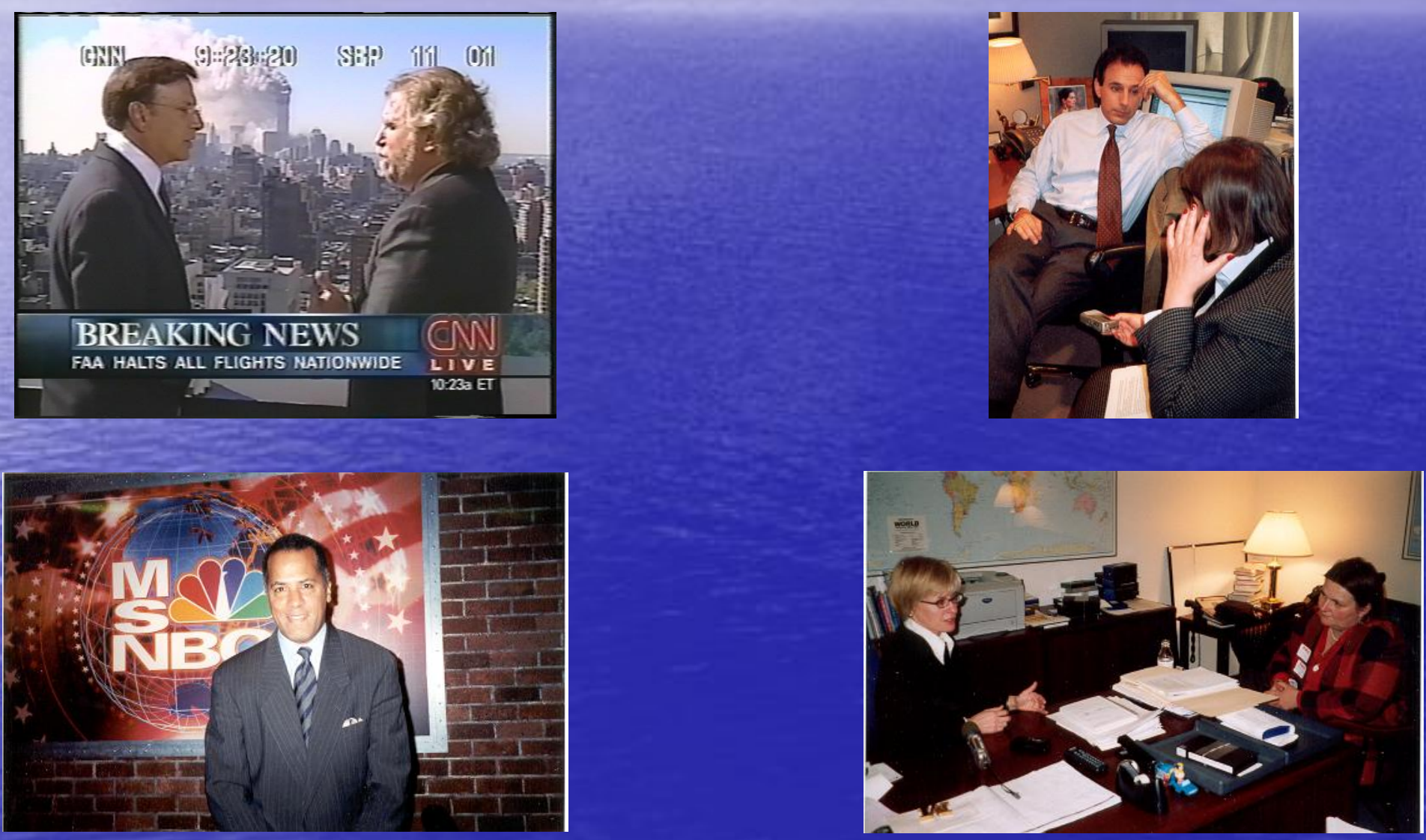


\section{Respect for natjonal security}
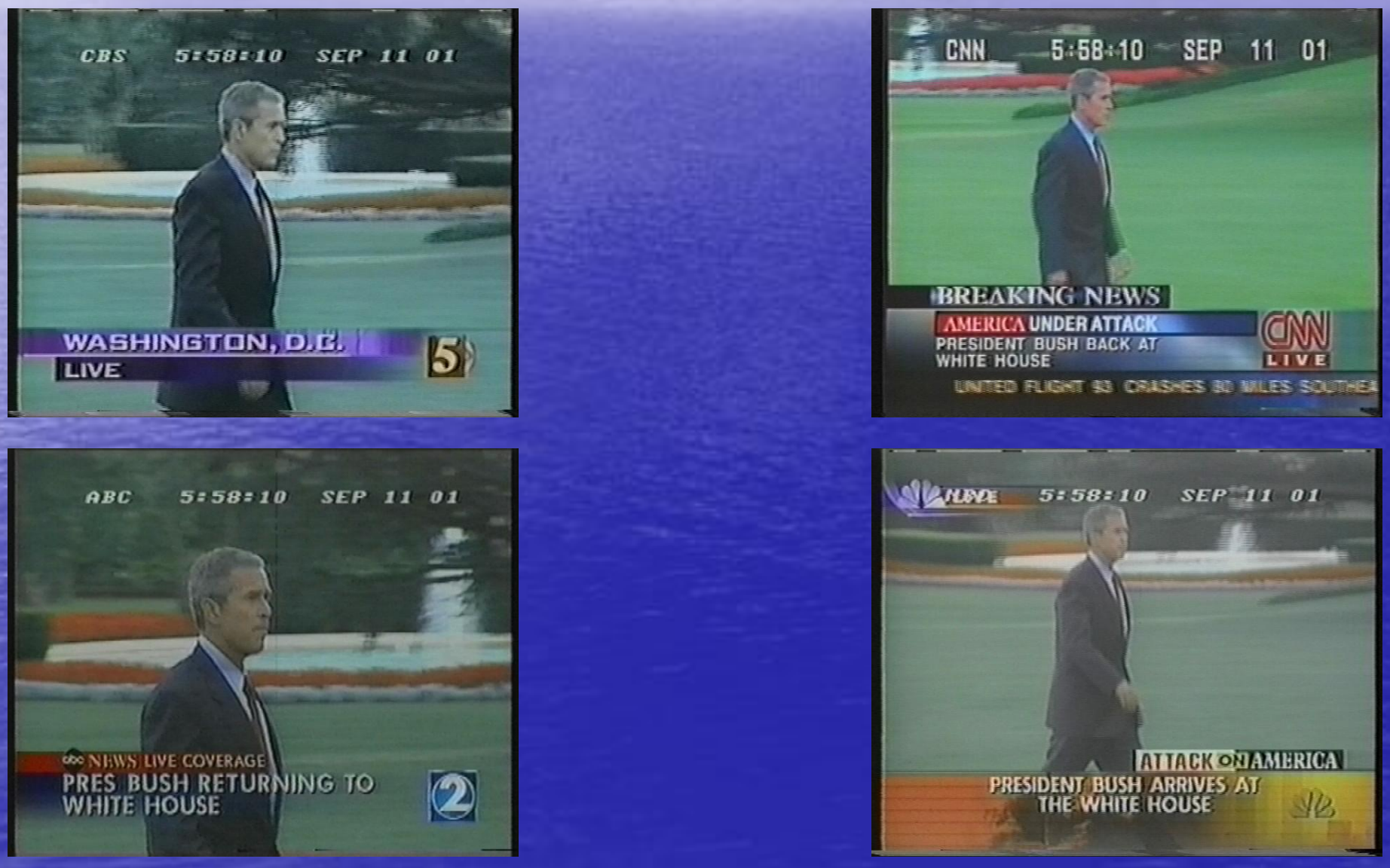